\title{
Effect of Salt Stress (Potassium Chloride) on the Ecological and Physiological Characteristics of Safflower (Carthamus tinctorius L.) Varieties
}

\author{
Sema LEBLEBİCi $\dot{I}^{1,2^{*}} \quad$ Şifanur SÜLÜŞ $^{3} \quad$ Gülçin ÇETIN KILIÇASLAN ${ }^{1}$ \\ ${ }^{1 *}$ Faculty of Arts and Sciences, Bilecik Seyh Edebali University, Bilecik, Turkey \\ ${ }^{2}$ Biotechnology Application and Research Center, Bilecik Şeyh Edebali University, Bilecik, Turkey \\ ${ }^{2}$ Institue of Science, Bilecik Şeyh Edebali University, Bilecik, Turkey
}

How to cite: Leblebici, S., Sülüş, Ş. \& Kılıçaslan, G.Ç. (2021). Effect of salt stress (Potassium chloride) on the ecological and physiological characteristics of safflower (Carthamus tinctorius L.) varieties. J. Anatolian Env. and Anim. Sciences, 6(3), 441-448.

Atıf yapmak için: Leblebici, S., Sülüss, S.̧. \& Kılıçaslan, G.Ç. (2021). Tuz stresinin (Potasyum klorür) aspir (Carthamus tinctorius L.) çeşitlerinin ekolojik ve fizyolojik özelliklerine etkisi. Anadolu Çev. ve Hay. Dergisi, 6(3), 441-448.

: https://orcid.org/0000-0002-3762-6408

https://orcid.org/0000-0002-4326-6568 https://orcid.org/0000-0002-9625-224X
*Corresponding author's: Sema LEBLEBICI

Bilecik Seyh Edebali University, Faculty of Arts and Sciences, Department of Molecular Biology and Genetics, Bilecik, Turkey 凶: leblebicisema@gmail.com

\begin{abstract}
Salinity, which is a significant abiotic stress factor, is among the most important factors that limit product quality and yield. In this study investigated phenological and physiological changes that occurred in three different safflower varieties that were exposed to $\mathrm{KCl}$ stress at concentrations of $0,50,100$ and $150 \mathrm{mM}$. It was found that, based on increasing salt concentrations, the most significant decrease was in all phenological parameters at the concentrations of 100 and $150 \mathrm{mM} \mathrm{KCl}$. The SOD and CAT activities showed a significant increase at high salt concentrations in the Balc1 and Dinçer varieties. The APX and GR activities showed a parallelism in all safflower varieties, and they showed a significant increase based on increased concentration at the applications of 100 and $150 \mathrm{mM} \mathrm{KCl}$. Among the three safflower varieties, the most resistant variety to salt application was Dinçer, while the most sensitive one was Remzibey. The Balcı variety was closer to the Dinçer variety in terms of its tolerance against salt stress.
\end{abstract}

Keywords: Antioxidant enzymes, phenological parameters, safflower, salt stress, seedling.

\section{Tuz Stresinin (Potasyum Klorür) Aspir (Carthamus tinctorius L.) Çeşitlerinin Ekolojik ve Fizyolojik Özelliklerine Etkisi}

\begin{abstract}
Öz: Önemli bir abiyotik stres faktörü olan tuzluluk, bitkilerde ürün kalitesini ve verimini ciddi şekilde sınırlandırmaktadır. Bu çalışmada, 0, 50, 100 ve $150 \mathrm{mM} \mathrm{KCl}$ uygulanan üç farklı aspir çeşidinde meydana gelen fenolojik ve fizyolojik değişiklikler incelenmiştir. Artan tuz konsantrasyonlarına bağlı olarak en önemli azalmanın tüm fenolojik parametrelerde 100 ve 150 $\mathrm{mM} \mathrm{KCl}$ konsantrasyonlarında olduğu belirlenmiştir. Balcı ve Dinçer çeşidinde yüksek tuz konsantrasyonlarında SOD ve CAT aktiviteleri önemli bir artış göstermiştir. APX ve GR aktiviteleri tüm aspir çeşitlerinde paralellik göstermiş, 100 ve $150 \mathrm{mM} \mathrm{KCl}$ uygulamasında önemli bir artış göstermiştir. Üç Aspir çeşidi karşılşatırıldığında tuz stresine en dayanıklı çeşidin Dinçer, en hassas çeşidin Remzibey olduğu; Balcı çeşidinin ise tuz stresine tolerans bakımından Dinçer çeşidine daha yakın olduğu tespit edilmiştir.
\end{abstract}

Sema LEBLEBICI

Bilecik Seyh Edebali Üniversitesi, Fen-

Edebiyat Fakültesi, Moleküler Biyoloji ve

Genetik Bölümü, Bilecik, Türkiye

凶: leblebicisema@gmail.com

Anahtar kelimeler: Antioksidan enzimler, aspir, bitki gelișimi, fenolojik parametreler, tuz stresi.

\section{INTRODUCTION}

Safflower, which is an important industrial plant, has an important potential in bringing barren and poor areas into production (Danicic et al., 2016). Safflower is one of the alternative products to be evaluated in dry and irrigated farming areas due to its better adaptation to arid regions, tolerance to high and low temperatures and salt stress, and high competition against weeds (Danicic et al., 2016; El-Shourbagy et al., 2017; Gengmao et al., 2015).

Soil salinity is an important abiotic stress factor that causes a decrease in agricultural production and is effective in the distribution of wild species. The salt tolerances of plant species and even varieties belonging to the same species show great variation (Elouaer and Hannachi, 2012). High amounts of salt negatively affect 
seed germination, plant morphology, early development stages and later stages of growth (Acosta-Motos et al., 2017). Salinity reduces the amount of water in the seed by first removing the osmotic potential, and in the second stage, it causes a change in enzyme activity along with toxicity (Elouaer and Hannachi, 2012). It prevents plant development by affecting cell division and growth. It causes a decrease in mitotic activity and cell division rate in the root and stem in plants (Fahad et al., 2015). In the early development stage of the embryo, it directly affects the structural organization or synthesis of proteins. Besides, high $\mathrm{KCl}$ concentrations affect water and ion transport, disrupting plant nutrient status, ionic balance and physiological processes (Golldack et al., 2014). The growth and development of the plant is significantly affected, the growth slows down, and this process results in plant death (Elouaer and Hannachi, 2012).

Salinity causes oxidative stress through the increased formation of reactive oxygen species (ROS) like other abiotic stresses (Singh et al., 2015; Sourour et al., 2014). Excessive accumulation of ROS is highly cytotoxic due to their reactivity with various basic cellular components (Sharma et al., 2012; Sourour et al., 2014). High ROS concentrations adversely affect intracellular ionic homeostasis, activation of proteases and endonucleases, cell membrane integrity, protein synthesis, enzyme activities and photosynthesis efficiency (Gengmao et al., 2015; Golldack et al., 2014; Hussain and Al-Dakheel, 2018). This collective effect can lead to cell death (Kumari et al., 2015). Therefore, plants activate enzymatic and nonenzymatic antioxidant systems to prevent excessive ROS accumulation. The most common enzymatic antioxidant systems are superoxide dismutase (SOD), catalase (CAT) and ascorbate peroxidase (APX). These enzymes work in different parts of the cell and catalyse various reactions when cells are exposed to stress (Çulha Erdal \& Cakirlar, 2014; El-Shourbagy et al., 2017; Golldack et al., 2014). SOD converts free oxygen radicals produced by xanthine oxidase into oxygen and hydrogen peroxide. SOD is recognized as a crucial intracellular antioxidant defence against free radicals (Stephenie et al., 2020). Catalase, an enzymatic antioxidant, plays a critical role in preventing cellular damage by efficiently reducing hydrogen peroxide $\left(\mathrm{H}_{2} \mathrm{O}_{2}\right)$ to water and oxygen (Sharma et al., 2012). Ascorbate peroxidase is a central component of the AsAGSH cycle, and it plays a crucial role in controlling intracellular ROS levels. APX uses two AsA molecules to reduce $\mathrm{H}_{2} \mathrm{O}_{2}$ to water and two monodehydroascorbate (MDHA) molecules (Sharma \& Dubey, 2016). Glutathione reductase (GR), an enzyme linked to $\mathrm{NAD}(\mathrm{P}) \mathrm{H}$, catalyses the reduction of GSSG to GSH, thereby maintaining a high cellular reduced/oxidized glutathione (GSH/GSSG) ratio. (Couto et al., 2016).
The purpose of this study is to i) evaluate the effect of salt $(\mathrm{KCl})$ stress on three varieties of safflower plants at the germination and seedling stages, ii) identify salinity-tolerant safflower varieties and iii) determine some phenological and physiological characteristics of safflower varieties with different salt concentrations.

\section{MATERIALS AND METHODS}

Phenological Parameters: This study used three different Safflower (Carthamus tinctorius L.) varieties as Balcı, Dinçer and Remzibey. The seeds to be used in the experiments were randomly selected. The selected seeds were sterilized by keeping them in 10\% sodium hypochlorite $(\mathrm{NaOCl})$ for five minutes (Jabeen \& Ahmad, 2012). To conduct the germination experiments, a control group containing distilled water and groups containing 50, 100 and $150 \mathrm{mM} \mathrm{KCl}$ were prepared. The experiments were carried out with three replications. The seeds that were sown were kept in a 16-hour light/8-hour night photoperiod at $25^{\circ} \mathrm{C}$ and $60 \%$ humidity in a climatized room for 21 days. At the end of the 21 days, for the germinated individuals, the germination rate, root and shoot lengths, root and shoot fresh-dry weights, root and shoot biomasses and seed vigour indices were determined (Figure 1).

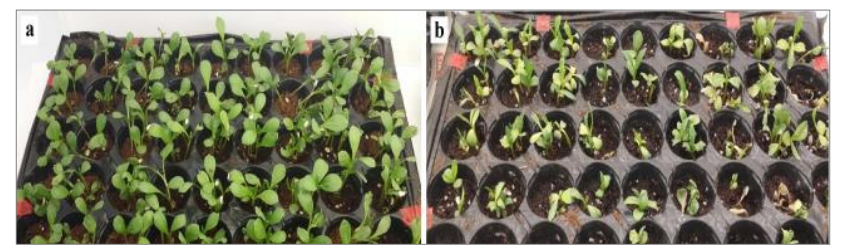

Figure 1. Plant samples a) Control groups, b) $150 \mathrm{mM} \mathrm{KCl}$ applied groups.

The total protein concentration and determination of antioxidant enzyme activities: The total protein contents in the leaf samples were determined using the Bradford (1976) method. To determine the total protein contents, $20 \mu \mathrm{l}$ of the enzyme solution was put onto $780 \mu \mathrm{l}$ $\mathrm{dH}_{2}$ O. $200 \mu \mathrm{l}$ of $5 \mathrm{X}$ Bradford solutions was added to this mixture. The mixture was kept in the dark and at room temperature for 5 minutes before the absorbance values were measured in triplicates in the spectrophotometer at the wavelength of $595 \mathrm{~nm}$. SOD activity was spectrophotometrically determined based on the method depending on photoreduction of Nitro blue tetrazolium (NBT) (Beyer \& Fridovich, 1987). CAT activity in the leaf samples was determined according to the method reported by Tepe and Aydemir (2011), GR activity was determined according to the method reported by Rao et al. (1996), while APX activity was determined by using the method of Cervilla et al. (2007). 
Statistical analysis and evaluation of results: Experimental results with control groups and safflower cultivars exposed to three different concentrations of $\mathrm{KCl}$ $(50,100$ and $150 \mathrm{mM})$ were statistically evaluated by using Tukey tests and one-way ANOVA (SPSS 21.0).

\section{RESULTS}

In the study, the results of three different $\mathrm{KCl}$ concentrations were compared with the control group of all three safflower cultivars. Experimental groups with statistically significant differences at the $\mathrm{p}<0.05$ level were determined. Considering the germination rate of the safflower varieties used in the study, it was seen that this rate decreased based on increased $\mathrm{KCl}$ concentrations $(p<0.05)$. When the varieties were compared, it was determined that the highest germination rate at the $100 \mathrm{mM}$ and $150 \mathrm{mM}$ salt concentrations was in the Dinçer variety (respectively $90 \% \pm 4,86 \% \pm 3$ ), while the lowest one was in the Balc1 variety (respectively $88 \% \pm 3,82 \% \pm 2$ ) (Figure 2).

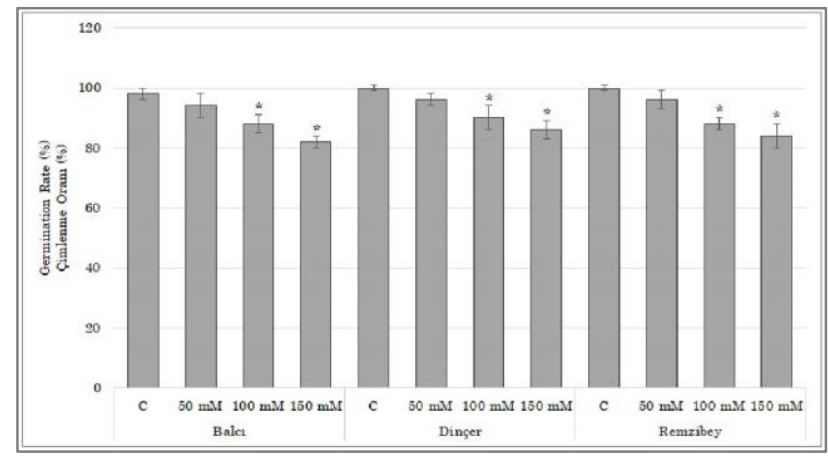

Figure 2. Seed germination rates for Safflower varieties $(\%)(* \mathrm{p}<0.05)$.

In the comparison of the seed vigour index, the lowest seed vigour index was at the concentration of 150 $\mathrm{mM} \mathrm{KCl}$ in Dinçer (75.8), while the highest was at $50 \mathrm{mM}$ $\mathrm{KCl}$ in Remzibey (92). Among the varieties, the highest seed vigour index (92) was in Remzibey, while the lowest (75.8) was in Dinçer (Figure 3).

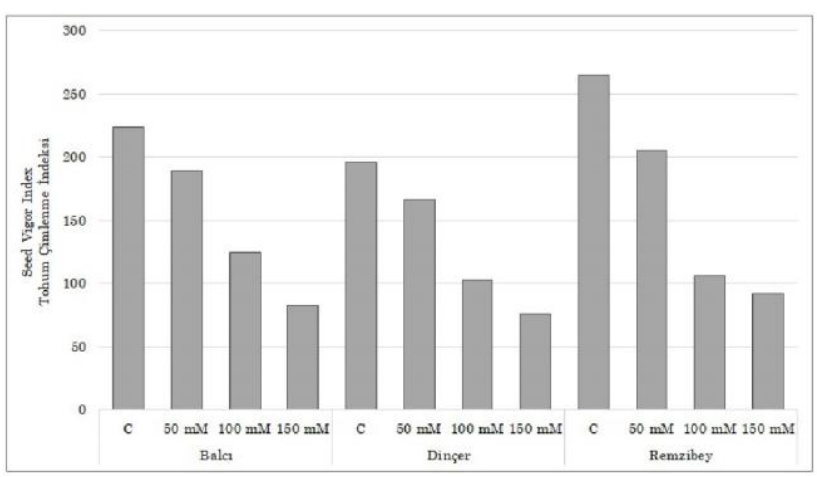

Figure 3. Seed vigor indices for Safflower varieties.

Based on increased salt concentrations, the root lengths of all varieties were shortened significantly $(\mathrm{p}<0.05)$. The Remzibey variety was the most affected by the $\mathrm{KCl}$ salt application, and it had the shortest root length at the $150 \mathrm{mM}$ concentration $(0.98 \pm 0.07 \mathrm{~cm})$ (Figure 4). The shoot lengths of all cultivars decreased significantly, depending on the increasing salt concentrations $(\mathrm{p}<0.05)$. The Dinçer variety was the most affected by the $\mathrm{KCl}$ salt application, and it had the shortest shoot length at the 150 $\mathrm{mM}$ concentration $(0.87 \pm 0.04 \mathrm{~cm})$ (Figure 4$)$. In all three safflower varieties, the reduction in the root and shoot lengths that occurred in the application of $100 \mathrm{mM}$ and 150 $\mathrm{mM} \mathrm{KCl}$ in comparison to the control group was found to be statistically significant $(\mathrm{p}<0.05)$ (Figure 4$)$. It was determined that the root and shoot fresh-dry weight was negatively affected by the increased $\mathrm{KCl}$ concentration and decreased significantly $(p<0.05)$. The decreases in the Balc variety at the 100 and $150 \mathrm{mM}$ salt applications in the root fresh weights $(0.13 \pm 0.004$ and $0.07 \pm 0.001 \mathrm{~g})$, in the Dinçer variety at the 50,100 and $150 \mathrm{mM}$ salt applications in the root fresh and dry weights (respectively $0.23 \pm 0.004$ $0.04 \pm 0.001 \mathrm{~g}, \quad 0.18 \pm 0.003-0.03 \pm 0.005 \mathrm{~g}, \quad 0.05 \pm 0.002-$ $0.01 \pm 0.003 \mathrm{~g})$ and in the Remzibey variety at the $50 \mathrm{mM}$ salt application in the root fresh weight $(0.12 \pm 0.005 \mathrm{~g})$ and at 100 and $150 \mathrm{mM}$ in the root fresh and dry weight (respectively $0.05 \pm 0.004-0.02 \pm 0.001 \quad \mathrm{~g}, \quad 0.03 \pm 0.004$ $0.01 \pm 0.004 \mathrm{~g})$ were found to be statistically significant $(\mathrm{p}<0.05)$ (Figure 5). The shoot fresh weight in the Balc1 variety at 100 and $150 \mathrm{mM}(0.67 \pm 0.01$ and $0.52 \pm 0.03 \mathrm{~g})$, the shoot fresh weight in the Dinçer variety at 50,100 and $150 \mathrm{mM}(1.47 \pm 0.04,1.24 \pm 0.01$ and $0.61 \pm 0.04 \mathrm{~g})$ and the shoot fresh weight in the Remzibey variety at 100 and 150 $\mathrm{mM}(0.65 \pm 0.01$ and $0.43 \pm 0.02 \mathrm{~g})$ were significantly lower than those of the controls $(\mathrm{p}<0.05)$ (Figure 6).

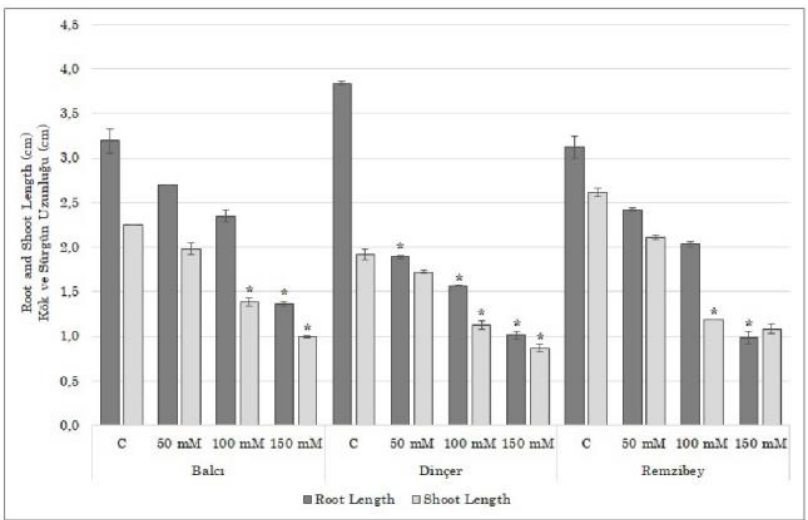

Figure 4. Root and shoot lengths for Safflower varieties (cm) $(* \mathrm{p}<0.05)$.

When the root and shoot biomasses of the control groups of the varieties were compared, the highest root $\left(626.1 \pm 5.75 \mathrm{~g} \mathrm{ha}^{-1}\right)$ and shoot $\left(3521.7 \pm 42.26 \mathrm{~g} \mathrm{ha}^{-1}\right)$ biomass was in the Dinçer variety, while the lowest root (321.7 $\left.\pm 5.50 \mathrm{~g} \mathrm{ha}^{-1}\right)$ and shoot $\left(2739.1 \pm 47.08 \mathrm{~g} \mathrm{ha}^{-1}\right)$ biomass was in the Remzibey variety. The reduction in the 
root and shoot biomass in the Balcı and Remzibey varieties at 100 and $150 \mathrm{mM}$ (respectively $195.7 \pm 8.41,132.8 \pm 6.41$ $\mathrm{g} \mathrm{ha}^{-1}$ and $\left.126.8 \pm 4.87,99.4 \pm 3.66 \mathrm{~g} \mathrm{ha}^{-1}\right)$ and the reduction in the Dinçer variety in the root (respectively $300.3 \pm 7.51$, $250.4 \pm 3.50$ and $93.4 \pm 8.83 \mathrm{~g} \mathrm{ha}^{-1}$ ) and shoot biomass (2465.2 $\pm 6.41,2817.3 \pm 34.55$ and $\left.1408.7 \pm 26.48 \mathrm{~g} \mathrm{ha}^{-1}\right)$ in all $\mathrm{KCl}$ concentrations were found to be statistically significant $(\mathrm{p}<0.05)$ (Figure 7).

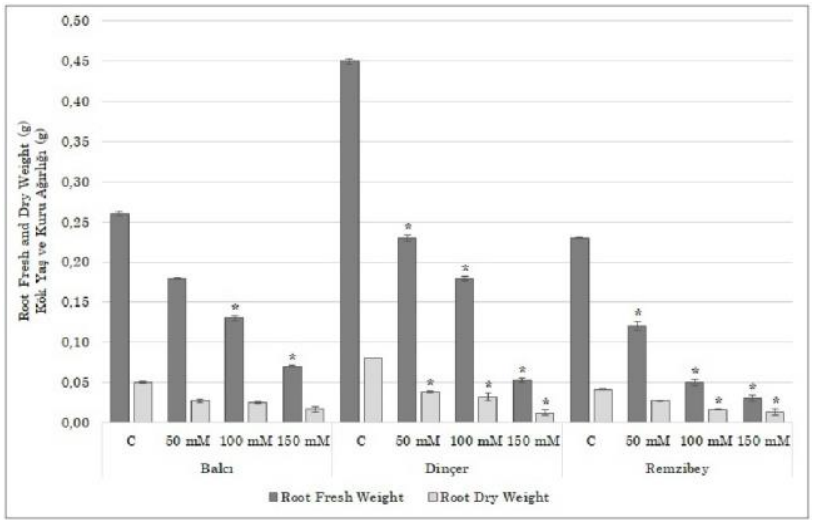

Figure 5. Root fresh and dry weights for Safflower varieties (g) $(* \mathrm{p}<0.05)$.

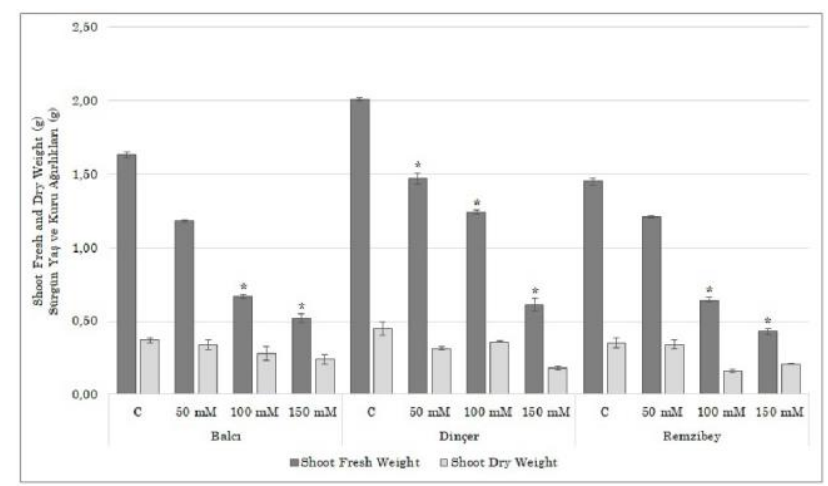

Figure 6. Shoot fresh and dry weights for Safflower varieties (g) $(* \mathrm{p}<0.05)$.

The SOD activity showed a significant increase at 100 and $150 \mathrm{mM} \mathrm{KCl}$ in the Balc1 variety based on the increasing salt concentrations $(p<0.05)$. As opposed to the Balcı variety, the Dinçer variety showed a decrease in SOD activity based on the increasing salt concentrations. The reduction in the Dinçer variety at $100 \mathrm{mM}$ and $150 \mathrm{mM}$ was statistically significant $(\mathrm{p}<0.05)$. The most significant increase in SOD in the Remzibey variety was determined at $150 \mathrm{mM}$ (Figure 8a). In the Balc1 variety, the CAT activity showed a decrease in comparison to the control as the salt concentration increased, and the reductions at 50 $\mathrm{mM}$ and $100 \mathrm{mM}$ were statistically significant $(\mathrm{p}<0.05)$ (Figure $8 b$ ). In the Dinçer variety, there was a remarkable decrease in the CAT activity as the $\mathrm{KCl}$ concentration increased $(\mathrm{p}<0.05)$. While there was a significant decrease at $50 \mathrm{mM}$ in the Remzibey variety in comparison to the control, a statistically significant increase was found at 100 $\mathrm{mM}$ and $150 \mathrm{mM} \mathrm{KCl}(\mathrm{p}<0.05)$ (Figure $8 \mathrm{~b}$ ).

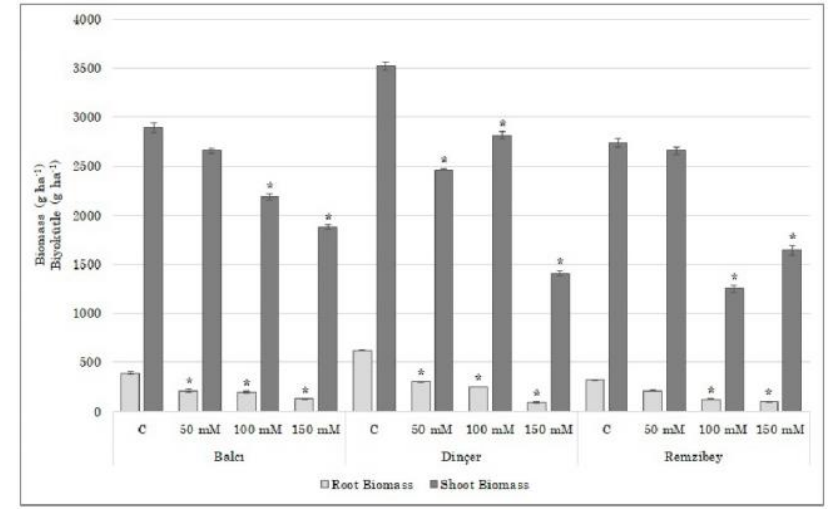

Figure 7. Root and shoot biomasses for Safflower varieties $(\mathrm{g} / \mathrm{ha})(* \mathrm{p}<0.05)$.

In the comparison of the safflower varieties, it was determined that the APX and GR activities increased based on the increasing $\mathrm{KCl}$ concentrations (Figure 9a, 9b). The increase in the APX activity was significant at 100 and 150 $\mathrm{mM}$ in the Balc1 variety and at all concentrations in the Dinçer variety. In the Remzibey variety, a significant increase was detected only at $150 \mathrm{mM} \mathrm{KCl}(\mathrm{p}<0.05)$ (Figure 9a). In terms of the GR activity, the increases at 100 and $150 \mathrm{mM}$ in the Balcı and Dinçer varieties and at $150 \mathrm{mM}$ in the Remzibey variety were significant $(\mathrm{p}<0.05)$ (Figure 9b).

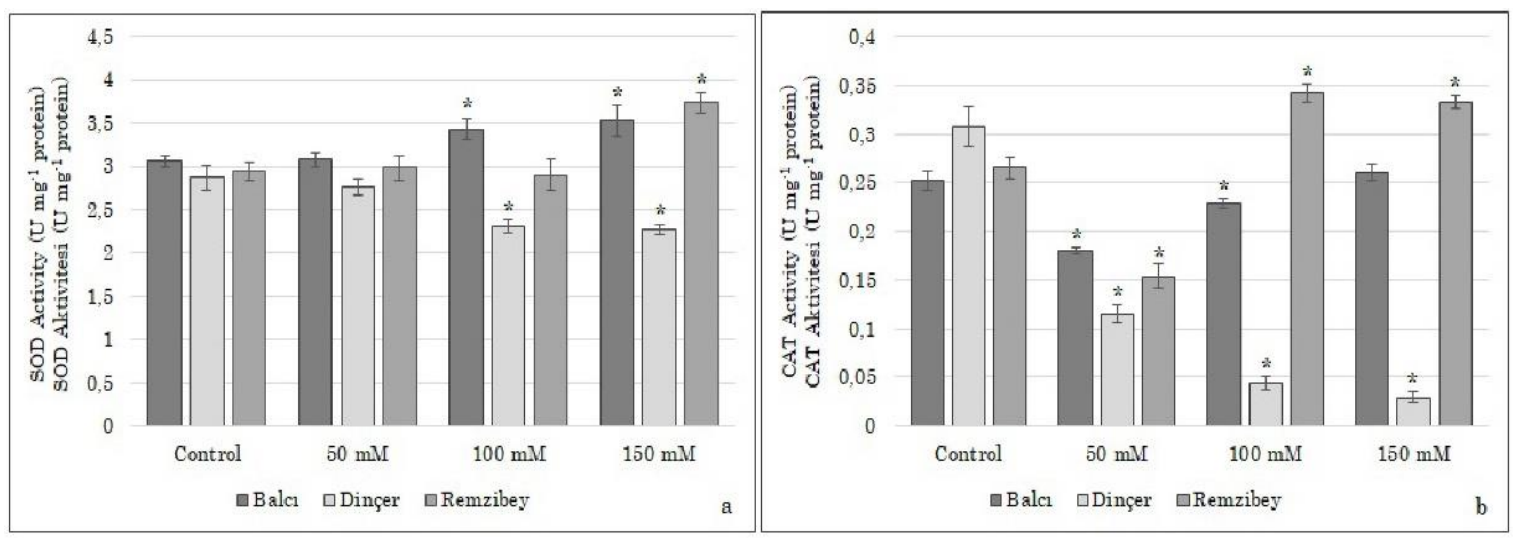

Figure 8. a) SOD and b) CAT activities for Safflower varieties $(* \mathrm{p}<0.05)$. 

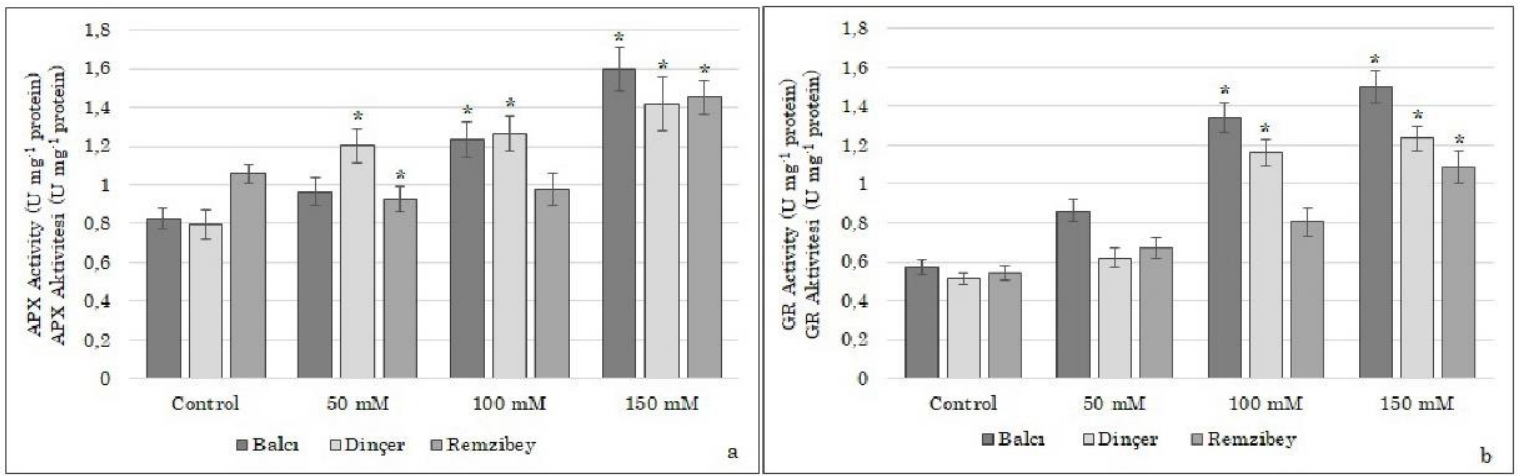

Figure 9. a) APX and b) GR activities for Safflower varieties (*p<0.05).

\section{DISCUSSION AND CONCLUSIONS}

Potassium chloride is the most widely used potassium source for agricultural crops, and $\mathrm{Cl}^{-}$is considered an essential micronutrient for optimum growth (Zaman et al., 2012). However, $\mathrm{KCl}$, which causes salinity, creates an osmotic potential outside the seed. This situation either inhibits water absorption or leads $\mathrm{K}$ and $\mathrm{Cl}$ to create a toxic effect. Thus, it causes a negative effect on seed germination. Salt tolerance in safflower is related to the ability to limit the uptake and transport of ions from the roots to the shoots. Safflower is a moderately salinitytolerant species, but it has been reported to be sensitive to salinity at the germination stage (Elouaer and Hannachi, 2012). It has been reported that salinity-affecting germination causes insufficient imbibition, ion toxicity, inhibition of metabolic activity, imbalance in growth regulators or induction of oxidative stress and prevents germination of seeds (Ahanger et al., 2017; Liang et al., 2018). In our study, it was determined that the germination rate decreased based on the increase in the salt concentration in the Balcı, Dinçer and Remzibey varieties. In particular, a statistically significant decrease was detected in all three safflower varieties at 100 and $150 \mathrm{mM}$ $\mathrm{KCl}(\mathrm{p}<0.05)$. There are many studies in the literature about the effects of salt stress on the germination rate. Similar to our study, Chen et al. (2021) reported that 150 $\mathrm{mM} \mathrm{KCl}$ and $\mathrm{NaCl}$ application reduced the seed germination rate in their study with sorghum (Chen et al., 2021). In the study conducted by Karimi et al. (2011), 0, $50,100,150$ and $200 \mathrm{mM} \mathrm{NaCl}$ was applied on five different safflower genotypes, and a short-term toxicity experiment was performed. It was reported that the percentage of germination decreased due to the increase in concentration at all salt concentrations except the control (Karimi et al., 2011). In a study conducted with six safflower genotypes, five different $\mathrm{NaCl}$ concentrations were applied $(0,-0.3,-0.5,-1$ and $-1.5 \mathrm{MPa})$, where the lowest germination rate was determined at $-1.5 \mathrm{MPa}$ (Khodadad, 2011).
In our study, the seed vigour index, which is another parameter related to germination, was compared among different varieties. In all three varieties, it was determined that the seed vigour index decreased at high salt concentrations, and the lowest seed vigour index was at the concentration of $150 \mathrm{mM} \mathrm{KCl}$. Numerous studies in the literature have shown that salt stress significantly reduces seed vigour in many species, inhibiting germination and early seedling growth (Chen et al., 2021; Elouaer and Hannachi, 2012; Isik \& Leblebici, 2016; Zaman et al., 2012).

Salt stress imposed during this period prevents plant growth by affecting cell division and elongation. It causes a decrease in mitotic activity and cell division rate in the root and stem. It inhibits the growth of the primary root system as a result of suppressing the cell cycle. Moreover, root hairs exposed to high salt concentrations become damaged and lose their activity (Sulus \& Leblebici, 2020). In our study, Dinçer and Remzibey varieties were the most affected in the high $\mathrm{KCl}$ application. The decrease in the root and shoot length at 100 and $150 \mathrm{mM} \mathrm{KCl}$ in all three safflower varieties was found to be statistically significant in comparison to the control group $(p<0.05)$. Similarly, it was determined that the root-shoot wet and dry weights decreased as a result of being negatively affected by the increasing $\mathrm{KCl}$ concentrations. As in other parameters, both root and stem biomass decreased based on the increasing $\mathrm{KCl}$ concentrations. The decrease in the root and shoot biomass of the three varieties at 100 and $150 \mathrm{mM} \mathrm{KCl}$ was found to be statistically significant $(\mathrm{p}<0.05)$. There are many studies in the literature on salt stress and phenological parameters. However, in many of these studies, $\mathrm{NaCl}$ has been used as a stress factor, and studies using $\mathrm{KCl}$ have been very rare. The results of studies in the literature have supported the data we obtained. In their study with sorghum, Chen et al. (2021) reported that $150 \mathrm{mM} \mathrm{KCl}$ application significantly reduced root length, shoot length, root fresh weight, shoot fresh weight, root dry weight and shoot dry weight by salt stress (Chen et al., 2021). In another study, $5 \mathrm{NaCl}$ 
concentrations of $0,-0.3,-0.5,-1$ and $-1.5 \mathrm{MPa}$ were applied on six different safflower varieties. It was stated that root-shoot length and the root/shoot length ratio decreased significantly at $-1.5 \mathrm{MPa}$ (Khodadad, 2011). Five different safflower genotypes were used in the study of Karimi et al. (2011). 0, 50, 100 and $200 \mathrm{mM} \mathrm{NaCl}$ was applied on plant samples. It was reported that application of 100 and $200 \mathrm{mM} \mathrm{KCl}$ significantly reduced root-shoot length and root-shoot wet and dry weights (Karimi et al., 2011). In the study of Gengmao et al. (2015), 0, 50, 100 and $150 \mathrm{mM} \mathrm{NaCl}$ was applied on safflower seedlings for 30 days. The authors reported that the plant height, root length and plant dry weight of the samples were not affected at salt concentrations below $100 \mathrm{mM}$ (Gengmao et al., 2015). Javed et al. (2014) used six safflower varieties in their study. They observed that salt stress significantly reduced the fresh and dry weights of the plant samples. They found that plant height and root length decreased depending on the increasing $\mathrm{NaCl}$ concentration (Javed et al., 2014). Studies with safflower have stated that root and stem biomass decreased at high salt concentrations, similar to the results of our study (Gengmao et al., 2015; Hussain \& Al-Dakheel, 2018; Siddiqi et al., 2011; Zao et al., 2021).

Plants counteract stresses caused by changing ecological conditions by increasing their ROS production. Changes in ROS levels are controlled by the efficient work of antioxidant enzymes. Inadequate functioning of the antioxidant system leads to cellular degradation, occurrence of abnormalities in the metabolism, and ultimately, ROS-induced oxidative stress (Acosta-Motos et al., 2017; Ahanger et al., 2017; Golldack et al., 2014). In our study, depending on the increasing salt concentrations, the SOD activity increased in the Balc1 and Remzibey varieties, but it decreased in the Dinçer variety. While the CAT activity decreased in the Balcı and Dinçer varieties, it increased in the Remzibey variety. The APX and GR activity increased in all varieties depending on the increasing salt concentrations. In particular, the increases at 100 and $150 \mathrm{mM} \mathrm{KCl}$ in the SOD, APX and GR activities and changes at all concentrations in the CAT activity were found to be statistically significant $(\mathrm{p}<0.05)$. In a study, 5 different $\mathrm{NaCl}$ solutions at concentrations of $0.06 \mathrm{~mol} \mathrm{~L}^{-1}, 0.12 \mathrm{~mol} \mathrm{~L}^{-1}, 0.18 \mathrm{~mol} \mathrm{~L}^{-1}, 0.24 \mathrm{~mol} \mathrm{~L}^{-1}$ and $0.30 \mathrm{~mol} \mathrm{~L}^{-1}$ were applied to two safflower varieties (TSF1 and SM). It was reported that SOD, CAT and APX activity increased in parallel with an increase in the $\mathrm{NaCl}$ concentrations. Additionally, it has been determined that the increase in the enzyme activities in the tolerant variety TSF1 was higher than that in the sensitive variety SM (Tian et al., 2019). Gengmao et al. (2015) applied 0, 50, 100 and $150 \mathrm{mM} \mathrm{NaCl}$ on safflower plants along 30 days. They reported that SOD and CAT activities increased significantly at all $\mathrm{NaCl}$ concentrations in comparison to the control. The authors stated that plant samples are resistant to medium-dose $\mathrm{NaCl}$ application (Gengmao et al., 2015). It was determined that SOD, CAT and POD activities were increased in safflower treated with 150 mmol L ${ }^{-1} \mathrm{NaCl}$ (Siddiqi et al., 2011).

In a study which used the Arak, Isfahan, Horasan, C111, AC-Stirling and Saffire varieties of safflower, 5 different $\mathrm{NaCl}$ concentrations of $0,50,100,150$ and 200 $\mathrm{mM}$ were applied on the varieties. It was reported that SOD and APX activities differed between the genotypes. It was determined that the SOD and APX activity of the Isfahan variety increased at $200 \mathrm{mM}$, and the superior genotype was Isfahan (Golkar \& Taghizadeh, 2018). In a study conducted with the Dinçer, Yenice and Remzibey varieties, it was stated that SOD activity increased significantly in Dinçer and Remzibey at $75 \mathrm{mM} \mathrm{NaCl}$ and higher salt concentrations. In the high-dose salt application, while the APX and GR activity of the Dinçer variety increased, the APX activities of the other varieties decreased. The lowest SOD, APX and GR activity was determined in the Remzibey variety (Çulha Erdal \& Çakirlar, 2014). In the study by Karimi et al. (2011), five different $\mathrm{NaCl}$ concentrations $(0,50,100,150$ and $200 \mathrm{mM})$ were applied on eight safflower varieties. It was reported that CAT activity decreased in most varieties grown under salt stress, and there were significant differences in the responses of the safflower varieties to salt stress (Karimi et al., 2011). In another study in which the Kairouan and Tazarka safflower varieties were used, 0 and $50 \mathrm{mM} \mathrm{NaCl}$ concentrations were applied on these varieties. It was reported that SOD, CAT and POD activity increased in Tazarka, and POD activity increased in Kairouan (KarrayBouraoui et al., 2011). These examples in the literature have revealed that enzyme activities may differ in different varieties of the same species in their processes of coping with stress. In our study, in parallel with the literature, differences in SOD and CAT activities between varieties were determined.

As a result, the first visible effects of salt stress, which is naturally present in the soil or caused by the secondary effect of global warming, appear on morphological parameters. In this study, it was determined that the germination rate, seed vigour index, root-shoot length, root-shoot wet and dry weight and root-shoot biomass decreased depending on the increasing $\mathrm{KCl}$ concentrations in three different safflower varieties (Balc1, Dinçer and Remzibey). The change in the activities of antioxidant enzymes that are involved in the scavenging of ROS caused by osmotic stress is one of the most important factors for the plant to cope with stress. In our study, it was determined that the SOD, CAT, APX and GR activities increased in high salinity in all three safflower varieties. However, it was determined that there was a difference 
between the Balcı and Dinçer varieties in terms of their SOD and CAT activities. Thus, it was demonstrated that different varieties of the same species may have different responses to stress. Considering the phenological and physiological results, it was determined that, among the three safflower varieties, the most resistant variety against the salt application was Dinçer, while the most sensitive one was Remzibey. The Balcı variety was closer to the Dinçer variety in terms of its tolerance against salt stress. In safflower cultivation in salty soils, the Dinçer variety may be recommended first, and the Balc1 variety may be recommended as the second.

\section{ACKNOWLEDGEMENTS}

This study was supported by Bilecik Şeyh Edebali University Scientific Research Projects Coordinatorship with the project number 2016-02.BŞEÜ.06-01.

\section{REFERENCES}

Acosta-Motos, J.R., Ortuño, M.F., Bernal-Vicente, A., Diaz-Vivancos, P., Sanchez-Blanco, M.J. \& Hernandez, J.A. (2017). Plant responses to salt stress: Adaptive mechanisms. Agronomy, 7(1), 138. DOI: $10.3390 /$ agronomy 7010018

Ahanger, M.A., Tomar, N.S., Tittal, M., Argal, S. \& Agarwal, R.M. (2017). Plant growth under water/salt stress: ROS production; antioxidants and significance of added potassium under such conditions. Physiology and Molecular Biology of Plants, 23(4), 731-744. DOI: 10.1007/s12298017-0462-7

Beyer, W.F. \& Fridovich, I. (1987). Assaying for superoxide dismutase activity: some large consequences of minor changes in conditions. Analytical Biochemistry, 161, 559-566. DOI: 10.1016/0003-2697(87)90489-1

Bradford, M.M. (1976). A rapid and sensitive metod for the quantitation of microgram quantities of protein utilizing the principle of protein-dye binding. Analytical Biochemistry, 72, 248-254. DOI: 10.1016/0003-2697(76)90527-3

Cervilla, L.M., Blasco, B., Ríos, J.J., Romero l. \& Ruiz, J.M. (2007). Oxidative stress and antioxidants in tomato (Solanum lycopersicum) plants subjected to boron toxicity. Annals of Botany, 100, 747-756. DOI: $10.1093 / \mathrm{aob} / \mathrm{mcm} 156$

Chen, X., Zhang, R., Xing, Y., Jiang, B., Li, B., Xu, X. \& Zhou, Y. (2021). The efficacy of different seed priming agents for promoting sorghum germination under salt stress. Plos One, 16(1), 1-14. DOI: 10.1371/journal.pone.0245505

Couto, N., Wood, J., \& Barber, J. (2016). The role of glutathione reductase and related enzymes on cellular redox homoeostasis network. Free Radical
Biology and Medicine, 95, 27-42. DOI: 10.1016/j.freeradbiomed.2016.02.028

Çulha Erdal, Ş. \& Çakirlar, H. (2014). Impact of salt stress on photosystem II efficiency and antioxidant enzyme activities of safflower (Carthamus tinctorius L.) cultivars. Turkish Journal of Biology, 38(4), 549-560. DOI: 10.3906/biy-1401-33

Danicic, M., Maksimovic, I. \& Putnik-Delic, M. (2016). Physiological and chemical characteristics of safflower (Carthamus tinctorius L.) grown in the presence of low salt concentrations. Zbornik Matice Srpske Za Prirodne NaukeMatica Srpska Journal for Natural Sciences, 130, 85-91. DOI: 10.2298/ZMSPN1630085D

Elouaer, M.A. \& Hannachi, C. (2012). Seed priming to improve germination and seedling growth of safflower (Carthamus tinctorius) under salt stress. EurAsian Journal of BioSciences, 6, 76-84. DOI: 10.5053/ejobios.2012.6.0.9

El-Shourbagy, M., Saad-Allah, K., Foda, S. \& Razzaky, E. (2017). Impact of Some Halophytic Extracts on the Antioxidant System of Salt-Stressed Safflower (Carthamus tinctorius L.). Journal of Plant Production, 8(7), 759-765. DOI: 10.21608/jpp.2017.40567

Fahad, S., Hussain, S., Matloob, A., Khan, F.A., Khaliq, A., Saud, S., Hassan, S., Shan, D., Khan, F., Ullah, N., Faiq, M., Khan, M.R., Tareen, A.K., Khan, A., Ullah, A., Ullah, N. \& Huang, J. (2015). Phytohormones and plant responses to salinity stress: a review. Plant Growth Regulation, 75(2), 391-404. DOI: 10.1007/s10725-014-0013-y

Gengmao, Z., Yu, H., Xing, S., Shihui, L., Quanmei, S. \& Changhai, W. (2015). Salinity stress increases secondary metabolites and enzyme activity in safflower. Industrial Crops and Products, 64(1), 175-181. DOI: 10.1016/j.indcrop.2014.10.058

Golkar, P. \& Taghizadeh, M. (2018). In vitro evaluation of phenolic and osmolite compounds, ionic content, and antioxidant activity in safflower (Carthamus tinctorius L.) under salinity stress. Plant Cell, Tissue and Organ Culture, 134(3), 357-368. DOI: 10.1007/s11240-018-1427-4

Golldack, D., Li, C., Mohan, H. \& Probst, N. (2014). Tolerance to drought and salt stress in plants: Unraveling the signaling networks. Frontiers in Plant Science, 5(APR): 1-10. DOI: 10.3389/fpls.2014.00151

Hussain, M.I. \& Al-Dakheel, A. (2018). Effect of salinity stress on phenotypic plasticity, yield stability, and signature of stable isotopes of carbon and nitrogen in safflower. Environmental Science and Pollution Research, 25, 23685-23694. DOI: 10.1007/s11356018-2442-z

Isik, G. \& Leblebici, S. (2016). Seed germination behavior of some safflower ( $C$. tinctorius L.) varieties according to habitat conditions containing different concentrations of boric acid. Pakistan Journal of Botany, 48(6), 2211-2214.

Jabeen, N. \& Ahmad, R. (2012). Improvement in growth and leaf water relation parameters of Sunflower and 
Safflower plants with foliar application of nutrient solutions under salt stress. Pakistan Journal of Botany, 44(4), 1341-1345.

Javed, S., Bukhari, S.A., Yasin Ashraf, M., Mahmood., S. \& Iftikhar, T. (2014). Effect of salinity on growth, biochemical parameters and fatty acid composition in safflower (Carthamus tinctorius L.). Pakistan Journal of Botany, 46(4), 1153-1158.

Karimi, N., Soheilikhah, Z., Ghasmpour, H.R. \& Zebarjadi, A. (2011). Effect of salinity stress on germination and early seedling growth of different Safflower (Carthamus tinctorius L.) genotypes. Journal of Ecobiotechnology, 3(10), 07-13.

Karray-Bouraoui, N., Harbaoui, F., Rabhi, M., Jallali, I., Ksouri, R., Attia, H., Msilini, N. \& Lachaal, M. (2011). Different antioxidant responses to salt stress in two different provenances of Carthamus tinctorius L. Acta Physiologiae Plantarum, 33, 1435-1444. DOI: 10.1007/s11738-010-0679-3

Khodadad, M. (2011). An evaluation of safflower genotypes (Carthamus tinctorius L.), seed germination and seedling characters in salt stress conditions. African Journal of Agricultural Research, 6(7), 1667-1672. DOI: 10.5897/AJAR10.915

Kumari, A., Das, P., Parida, A.K. \& Agarwal, P.K. (2015). Proteomics, metabolomics, and ionomics perspectives of salinity tolerance in halophytes. Frontiers in Plant Science, 6, 537. DOI: 10.3389/fpls.2015.00537

Liang, W., Ma, X., Wan, P. \& Liu, L. (2018). Plant salttolerance mechanism: A review. Biochemical and Biophysical Research Communications, 495(1), 286-291. DOI: 10.1016/j.bbrc.2017.11.043

Rao, M.V., Paliyath, G. \& Ormrod, D.P. (1996). Ultraviolet-B- and ozone-induced biochemical changes in antioxidant enzymes of Arabidopsis thaliana. Plant Physiology 110, 125-136. DOI: 10.1104/pp.110.1.125

Sharma, P., Jha, A.B. \& Dubey, R.S. (2016). Oxidative stress and antioxidative defense systems in plants growing under abiotic stresses. Handbook of Plant and Crop Stress Third Edition, 89-138.

Sharma, P., Jha, A.B., Dubey, R.S. \& Pessarakli, M. (2012). Reactive Oxygen Species, Oxidative Damage, and Antioxidative Defense Mechanism in Plants under Stressful Conditions. Journal of Botany, 2012, 1-26. DOI: 10.1155/2012/217037

Siddiqi, E.H., Ashraf, M., Al-Qurainy, F. \& Akram, N.A. (2011). Salt-inducedmodulation in inorganic nutrients, antioxidant enzymes, proline content and seed oil composition in safflower (Carthamus tinctorius L.). Journal of the Science of Food and Agriculture, 91, 2785-2793. DOI: $10.1002 /$ jsfa. 4522

Singh, M., Kumar, J., Singh, S., Singh, V.P. \& Prasad, S.M. (2015). Roles of osmoprotectants in improving salinity and drought tolerance in plants: a review. Reviews in Environmental Science and Biotechnology, 14(3), 407-426. DOI: 10.1007/s11157-015-9372-8
Sourour, A., Rassaa, N., Chamekh, Z., Beji, S., Karouı, F., Bouzaien, T., Mrabit, M. \& Ben Younes, M. (2014). Effect of salt stress (sodium chloride) on germination and seedling growth of durum wheat (Triticum durum Desf.) genotypes. International Journal of Biodiversity and Conservation, 6(4), 320-325. DOI: 10.5897/IJBC2013.0668

Stephenie, S., Chang, Y.P., Gnanasekaran, A., Esa, N.M. \& Gnanaraj, C. (2020). An insight on superoxide dismutase (SOD) from plants for mammalian health enhancement. Journal of Functional Foods, 68(November 2019), 103917. DOI: 10.1016/j.jff.2020.103917

Sulus, S., Leblebici, S. (2020). The effect of boric acid application on ecophysiological characteristics of safflower varieties (Carthamus tinctorius L.). Fresenius Environmental Bulletin, 29(09A), 8177 8185.

Tepe, M. \& Aydemir, T. (2011). Antioxidant responses of lentil and barley plants to boron toxicity under different nitrogen sources. African Journal of Biotechnology, 10(53), 10882-10891. DOI: 10.5897/AJB10.1076

Tian, M., Cao, H.Y., Zhang, M.S., Zhang, Z.X., Yang, D.Y., Li, H.R., Ma, C.Y. (2019). Response of Carthamus tinctorius L. to salt stress during germination and seedling stage. Journal of Agricultural Science and Technology, 21(5), 49-54.

Zaman, B., Ali, A., Hyder, S.I., Arshadullah, M. \& Bhatti, S.U. (2012). Potassium chloride as a nutrient seed primer to enhance salt-tolerance in maize. Pesquisa Agropecuária Brasileira, 47(8), 1181-1184. DOI: $\quad$ 10.1590/S0100204X2012000800020

Zao, D., Gao, S., Zhang, X., Zhang, Z., Zheng, H., Rong, K., Zhao, W. \& Khan, S.A. (2021). Impact of saline stress on the uptake of various macro and micronutrients and their associations with plant biomass and root traits in wheat. Plant, Soil and Environment, 67(2), 61-70. DOI: 10.17221/467/2020-PSE 